TILTAI, 2017, 3, 63-88 ISSN 1392-3137 (Print), ISSN 2351-6569 (Online)

\title{
KŪRYBOS VISUOMENĖS POLITIKOS MODELIO IGYVENDINIMO DISKURSAS
}

\author{
Aurimas Venckūnas \\ Vytauto Didžiojo universitetas
}

\begin{abstract}
Anotacija
Atliekant tyrimą siekta sudaryti kūrybos visuomenès politikos ịgyvendinimo modelị, kuris atskleidžia, kaip Lietuvoje vyksta viešosios politikos procesas. Pagrindinis tyrimo metodas - ilgalaikè dokumentu analizè (atlikta 2011-2015 metais). Rezultatai - sudarytas kūrybos visuomenès politikos igyvendinimo modelis (remiantis juo ši politika gali būti kuriama ir įgyvendinama pavienėje šalyje). Atskleistos šios politikos Lietuvoje kūrimo kryptys (nustatytos rengiant šalies raidos strategiją): veikli, solidari, besimokanti visuomenè. Ir šios politikos Lietuvoje igyvendinimo (igyvendinant šalies raidos strategiją) kryptys: „greitos pergalès“ (kasmet Vyriausybė ịsipareigoja ịgyvendinti dešimt svarbių darbų); sisteminis strategijos įgyvendinimas (per strateginio planavimo dokumentų sistemą; be to, būtina turèti instituciją, kuri turi galių prižiūrèti visų lygmenų strategijų rengimo ir ịgyvendinimo eigą); bendruomenių ir nevyriausybinių organizacijų tiesioginis įtraukimas.

PAGRINDINIAI ŽODŽIAI: kūrybos visuomenè, dabartinė visuomenė, modelis, politika, viešosios politikos procesas.
\end{abstract}

\begin{abstract}
Aim of research is to make the model of implementation of creative society policy, showing the empirical process of public policy in Lithuania. The main method of research is a long-term (longitudinal) analysis of documents (performed in 2011-2015). Results are the model of implementation of creative society policy (the model shows how this policy can be formed and implemented in a separate country). Moreover, the following directions (determined during the preparation of the state development strategy) of formation of this policy in Lithuania were revealed: active society; solidary society; learning society. Furthermore, the following directions of implementation of this policy (through the state development strategy) in Lithuania were revealed: "quick wins" (commitment of the Government to take 10 important actions every year); systemic implementation of this strategy (through the system of strategic planning documents; as well, it is essential to have the proper institution, with the necessary powers to control the preparation and implementation of strategies in all levels); direct involvement of communities and non-governmental organizations.

KEYWORDS: creative society, contemporary society, model, policy, public policy process.
\end{abstract}

\section{Ivadas}

Viešosios politikos procesą aiškina ịvairios sampratos (Parsons, 2001, p. 50; Dunn, 2006): stadijinès, kai politikos procesas suvokiamas kaip paskirų žingsnių arba stadijų seka; pliuralistinès elito (Lindblom ir kt., 1999, kt.), kai dėmesys kreipiamas ị elito ịtaką formuojant politiką; neomarksistinés; posistemių; politinio diskurso; institucionalizmo, kai dẻmesys kreipiamas ị valstybės ir sociali- 
nių institucijų vaidmenį, apibrèžiant ir formuojant viešąją politiką. Vyraujančios yra stadijinės sampratos (Vilpišauskas ir kt., 2005, p. 41-44; Anderson, 2015, kt.), kai politikos procesas suvokiamas kaip ịvairių stadijų seka, dažnai prasidedanti nuo problemos apibrěžimo ir darbotvarkès rengimo (Kingdon, 2014), apimanti sprendimų prièmimą (Stone, 2004), kuris sieja politikos formavimą su jos įgyvendinimu, ir pasibaigianti politikos ịgyvendinimo rezultatų ịvertinimu. Kita vertus, tikras pasaulis yra sudètingesnis, jis nepadalytas ị aiškiai apibrezžtus ciklus ir fazes (Parsons, 2001, p. 85). Straipsnyje, tiriant kūrybos visuomenès politikos (kaip viešosios politikos srities) procesą, remiamasi paskiroje šalyje (Lietuvoje) išryškejjusiomis šios politikos krypčių nustatymo ir igyvendinimo stadijomis.

Problema: kaip ịgyvendinama kūrybos visuomenès politika (kaip gana nauja politika) paskiroje šalyje.

Tikslas: sudaryti kūrybos visuomenès politikos igyvendinimo modelị, kuris atskleidžia, kaip empiriškai (t. y. tikrovejje) vyksta viešosios politikos procesas.

Objektas: kūrybos visuomenès politikos (kaip gana naujos politikos) ịgyvendinimas Lietuvoje.

Tiriant kūrybos visuomenès politiką, kaip gana naują reiškinị, atsižvelgiama ị Lietuvoje išryškejjusius šios politikos krypčių nustatymo ir ịgyvendinimo procesus. Jie vykdomi igyvendinant Seimo nutarimu patvirtintą šalies raidos strategiją (ir šalies strateginio planavimo sistemą), Vyriausybės nutarimus, ministrų ịsakymus, remiantis Vyriausybės interneto svetaineje (ir oficialioje šalies raidos strategijos interneto svetainèje) pateikta informacija ir kitais susijusiais viešais (oficialiais) dokumentais.

Uždaviniai:

- pagrịsti kūrybos visuomenès politiką, kaip gana naują politiką (pagrindžiant pačią kūrybos visuomenę ir jos politikos svarbą);

- sukurti empiriškai pagrịstą kūrybos visuomenès politikos ịgyvendinimo modeli;

- atskleisti kūrybos visuomenès politikos Lietuvoje kūrimo kryptis;

- atskleisti kūrybos visuomenès politikos Lietuvoje igyvendinimo kryptis.

Tyrimo būdai ir metodai: mokslinès literatūros analizè (bendrasis metodas), dviejų atvejų (t. y. kūrybos visuomenés politikos Lietuvoje krypčių nustatymo ir iggyvendinimo) tyrimas, ilgalaikè (longitudinè) dokumentų analizè (atlikta 2011-2015 metais).

Šis straipsnis pradedamas literatūros analize, kuria siekta pagrịsti kūrybos visuomenès politiką, kaip gana naują politiką. Antroje dalyje pristatoma tyrimo metodologija. Trečioje dalyje pateikiami tyrimo rezultatai (sudaromas empiriškai 
pagrịstas kūrybos visuomenès politikos ịgyvendinimo modelis). Straipsnis baigiamas išvadomis (atitinka tyrimo tikslą ir uždavinius).

\section{Literatūros apžvalga}

Literatūros analize siekiama pagrịsti kūrybos visuomenès politiką, kaip gana naują politiką. Tai atliekama, pagrindžiant pačią kūrybos visuomenę (pagal visuomenès raidos požymị), kreipiant dèmesị ị augančią kūrybos klasę dabartinèje visuomeneje ir atskleidžiant kūrybos visuomenès politikos, kaip gana naujos politikos, svarbą.

\subsection{Kūrybos visuomenès pagrindimas (visuomenès raidos požymis)}

Dabartinès visuomenès tyrinèjimai - plati visuomenès tyrinejjimų sritis. Mokslininkai ir politikai iki šiol svarsto, kokioje visuomeneje mes gyvename ir koki vaidmeni atlieka technologijos bei informacija. XX amžiaus antrojoje pusejje ir XXI amžiuje dabartinei visuomenei (ir jos ekonomikai) apibūdinti sukurta daugybė sąvokų: žiniu ar informacine ekonomika, popramoniné visuomené, postmodernioji visuomene, informaciné visuomene, tinkline visuomene, informacinis kapitalizmas, tinklinis kapitalizmas ir kita. Tiksliau apibūdinti dabartinę visuomenę leidžia visuomenès raidos požymis. Atsižvelgiant ị technologijų kaitą, skiriami šeši visuomenès tipai (epochos): tradicinė visuomenè (iki 1800 metų), pramoninè visuomené (1800-1950 metai), popramoninè visuomenè (1950-1980 metai), žinių visuomenè - taip sutarta vadinti informacinę visuomenę pasaulio politikų UNESCO susitikime 2004 metais (1980-2000 metai), kūrybos visuomenè (nuo 2000 metų), svajonių visuomenè - būsimas tipas, aprašytas mokslininkų futurologų (Jensen, 2004; Vareikis, 2012; kt., žr. 1 pav.).

Istorinès raidos požiūris suteikia galimybę nagrinèti tokių tipų bruožus, atsiradimo (ar jų viešosios politikos formavimo) veiksnius ir alternatyvas. Dabartinė visuomenè minètu požiūriu gali būti apibūdinta kaip kūrybos visuomenè (Tvede, 2016; Kačerauskas, 2017, kt.). Žinoma, tokia visuomenè formuojasi savaime: tai rodo atlikti tyrimai apie augančią (ir nuo 2000 metų èmusią vyrauti) kūrybos klasę dabartinèje visuomeneje (Florida, 2002, p. 5; Kirvelis, 2007, p. 78) ir pastaruoju metu išryškèjęs kūrybos industrijų reiškinys (Caves, 2002, kt.). Savaime suprantama, kad turtingose šalyse kūrybos visuomenès bruožai labiau pastebimi, ne tokiose turtingose - mažiau. 


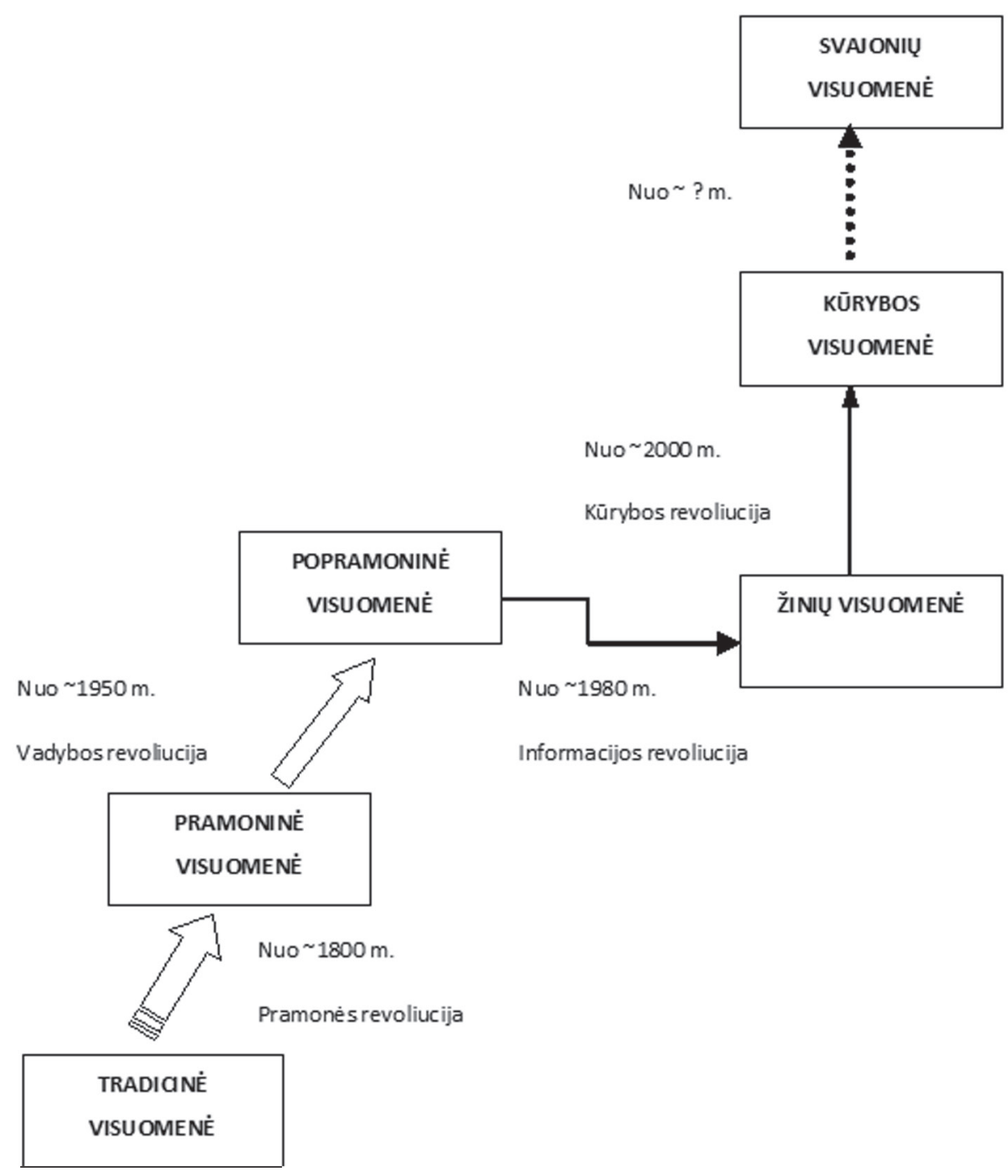

1 pav. Visuomenès tipų schema (remiantis Remeika ir kt., 2007, p. 2)

Fig. 1. The scheme of society types (according to Remeika et al., 2007, p. 2)

1.2. Pagrindiniai tyrimai apie augančią (ir vyraujančią) kūrybos klasę dabartinèje visuomenèje

Kad kūrybos klasès dalis dabartinèje visuomenèje auga (ir nuo 2000 metų èmè vyrauti), pagrindžiama ilgo laikotarpio (šimtmečio ar daugiau) duomenimis. Kaip 
rodo atlikti tyrimai (Florida, 2002, p. 5), per paskutinị šimtmetị JAV ịvairių sričių darbuotojų sudètis gerokai pasikeite ( 2 pav.). Sparčiai auga kūrybos klasė, kuri skaidoma dar į du sluoksnius: kūrybišką branduoli (angl. super-creative core) ir kūrybiškus darbuotojus (angl. creative professionals).

\section{ILGO LAIKOTARPIO (ŠIMTMEČIO) NAGRINÉJIMAS}

Kokie îvykiai per praẻjusị šimtmeti lèmé kūrybinés klasés augimą?

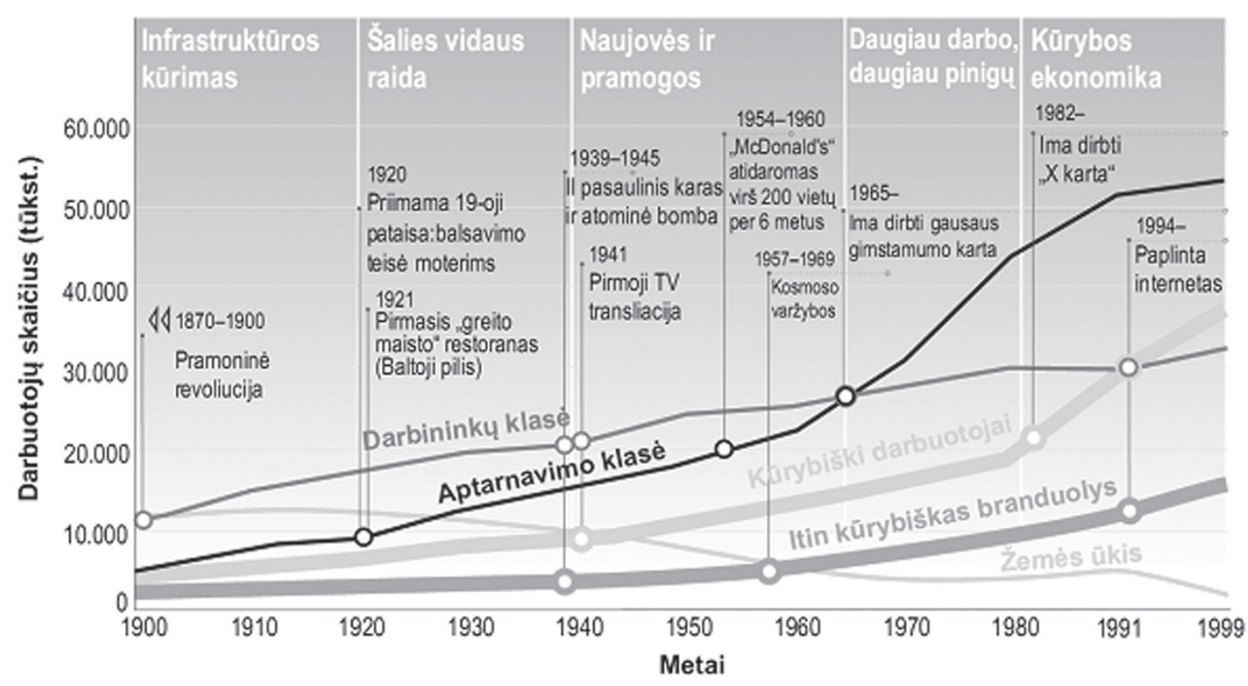

2 pav. JAV ịvairių sričių darbuotojų kaita XX amžiuje, tūkst. darbuotojų

(Florida, 2002, p. 5)

Fig. 2. Development of the US worker population in the $20^{\text {th }}$ century, in thousands of workers (Florida, 2002, p. 5)

Nagrinejjant ịvairiose srityse dirbančių žmonių skaičių dar ilgesnị laikotarpi (pradedant nuo tradicinès visuomenès tipo), išryškèja kūrybos klasės svarba dabartinëje visuomenejje (3 pav.).

Kadangi kūrybos klase dabartinèje visuomenejje yra svarbi, galima teigti, kad kūrybos visuomenė yra paskiras visuomenės tipas, kur kūrybos klasės atstovai sudaro bent 25-30 proc. visų šalies darbuotojų (Kirvelis, 2007, p. 28). Kaip minèta, kūrybos klasė gali būti skaidoma ị du sluoksnius: labai kūrybišką branduolị ir kūrybiškus darbuotojus (Florida, 2002, p. 5). Labai kūrybiškam branduoliui (sudare apie 12 proc. visų darbuotojų JAV 2002 metais) priskiriami mokslo ir inžinerijos, tyrimų ir plètros, programavimo srityse bei aukštosiomis technologijomis grịstose 
pramonės šakose dirbantys žmonès (Remeika ir kt., 2007, p. 2), taip pat meno, muzikos, kultūros, estetikos ir dizaino sričiu atstovai (jie sudaro nedidelę dalį). Kūrybiškiems darbuotojams priskiriami žiniomis, išmanymu pagrịstų profesijų atstovai sveikatos apsaugos, verslo bei finansinio tarpininkavimo, teisinių paslaugu ir švietimo srityse (mokslinèje literatūroje jie vadinami žinių darbuotojais). Vèliau atliktuose tyrimuose (Florida, 2012) kūrybos klasė skirstoma dar smulkiau, net ị keturis sluoksnius: technologijų ir mokslo darbuotojus, menų ir kultūros darbuotojus, verslo darbuotojus, sveikatos apsaugos ir švietimo darbuotojus. Kita vertus, nors kūrybos klasė suskirstyta smulkiau (i du ar ị keturis sluoksnius), bendras skaičius išlieka nepakitęs (šalyje, kur kūrybos visuomenè egzistuoja, ji sudaro bent 25-30 proc. visų darbuotojų).

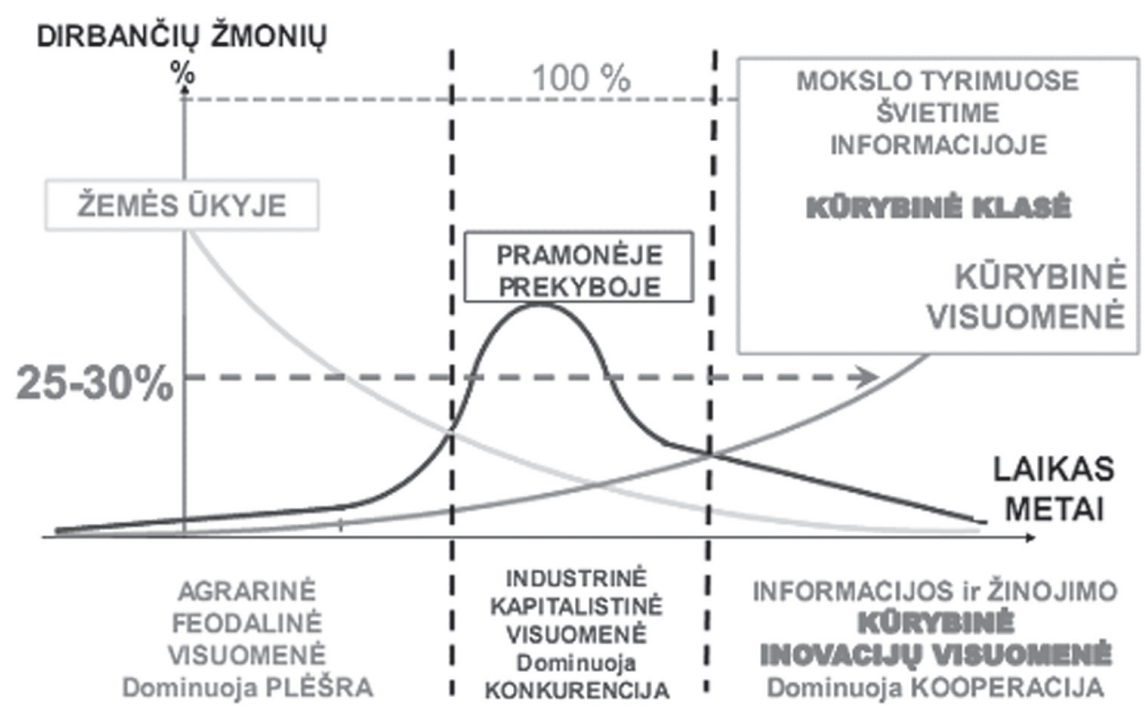

3 pav. Apibendrinta socialinès raidos schema (Kirvelis, 2007, p. 78)

Fig. 3. A generalized scheme of social development (Kirvelis, 2007, p. 78)

Tokių šalių pavyzdys 2000 metais buvo JAV, Belgija, Olandija, Suomija, Jungtinè Karalyste, Airija, kitose tyrime dalyvavusiose Europos šalyse (Graikijoje, Švedijoje, Danijoje, Ispanijoje, Vokietijoje, Austrijoje, Italijoje, Portugalijoje) minètų profesijų žmonių buvo mažiau, jie sudare tik 13-22 proc. (Florida ir kt., 2004, p. 14). Lietuvoje, vertinant apytikriai, minètų profesijų žmonès, atrenkant juos pagal ekonominès veiklos rūšis (Oficialiosios statistikos portalas, 2015), sudarytų 33 proc. visų šalies darbuotojų. 


\subsection{Kūrybos visuomenès politikos (gana naujos) svarba}

Kūrybos visuomenès politika yra gana naujas reiškinys. XXI amžiaus pradžioje atlikti tyrimai (KEA, 2006; 2009) atskleidè, kad kultūra ir ja pagrịstas kūrybiškumas yra vienas svarbiausių Europos konkurencingumo pasaulyje šaltinių, kuriuo pradeda domėtis Kinija ir Karibų šalys (KEA, 2011; World Bank, 2013, kt.). Pastaruoju metu pastebimas brandus tiek Europos Sajungos institucijų, tiek Lietuvos požiūris ị kultūrą (Europos Komisija, 2010; Gelūnas, 2010; European Commission, 2012), kultūros finansavimui skiriamas didelis politikų dèmesys (Kvietkauskas, 2011, kt.). Lietuvoje 2012 metais net įkurtas Kūrybos visuomenès ir ekonomikos institutas (Kazimiero Simonavičiaus universitete Vilniuje) bei Kūrybinių industrijų fakultetas (Vilniaus Gedimino technikos universitete). Kūrybos visuomenès politika svarbi viešojo intereso užtikrinimo požiūriu, tokia visuomenè numatyta šalies raidos strategijoje (Lietuvoje). Tokị sudètingą ir nevienamatį visuomeniškai ir politiškai svarbų reiškinị tirti, matyt, būtų geriausia, remiantis viešosios politikos (viešosios politikos kūrimo ir igyvendinimo) sampratomis, kurios yra esminè politikos mokslo dalis (Giest ir kt., 2015, p. 121).

Kūrybos visuomenès politika gali būti apibrèžta kaip gana nauja politika (viešosios politikos sritis), ịvardijanti kūrybos visuomenę ir atsiskleidžianti šalies Seimo, Vyriausybès nutarimuose bei kituose viešuosiuose dokumentuose. Kūrybos visuomenès politikos tikslas - kuo daugiau žmonių išugdyti gebantys susirasti savas ịgimtas kūrybines galias, gauti kuo aukštesnị išsilavinimą ir gyventi bei dirbti šioje srityje savame krašte (Kirvelis, 2011, p. 6).

\section{Tyrimo metodologija}

Straipsnyje, tiriant kūrybos visuomenès politikos (kaip viešosios politikos srities) procesą, taikomi ịvairūs tyrimo būdai ir metodai: mokslinès literatūros analizė (bendrasis metodas), dviejų atvejų (t. y. kūrybos visuomenès politikos Lietuvoje krypčių nustatymo ir igyvendinimo) tyrimas, ilgalaikè (longitudinè) dokumentų analizė (atlikta 2011-2015 metais). Pažymėtina, kad straipsnyje remiamasi viena pagrindinių pastarųjų dešimtmečių mokslinių tyrimų krypčių (The European Foresight Monitoring Network, 2008), kuri siūlo, tobulinant senus ar kuriant naujus metodus bei modelius ateities studijoms, taikyti kokybinio tyrimo (Tidikis, 2003, p. 355; Kardelis, 2007, p. 270; Luobikienè, 2010, p. 32; Flick, 2017) strategiją (straipsnyje ši strategija apima išvardytus tyrimo būdus ir metodus).

Mokslinès literatūros analizė yra neatsiejama mokslinio tyrimo dalis, ji gali būti ir „pagalbinè mokslinio tyrimo priemonè“, pavyzdžiui, eksperimentiniame 
tyrime; kai kuriais atvejais gali tapti savarankišku tyrimo metodu, pavyzdžiui, aprašomojo pobūdžio darbuose (Kardelis, 2007, p. 105). Straipsnyje mokslinės literatūros analizė atliekama, pagrindžiant kūrybos visuomenès politiką kaip paskirą gana naują politiką (t. y. pagrindžiant pačią kūrybos visuomenę ir jos politikos svarbą) ir sudarant paskiras kūrybos visuomenès politikos iqgyvendinimo modelio dalis (susijusios su ankstesnès politikos patirtimi, šalies raidos strategijos poveikiu ir strateginiu valdymu viešajame sektoriuje).

Atvejo tyrimas (Kardelis, 2007, p. 260; Luobikienè, 2010, p. 37; Van Thiel, 2014, p. 86) remiasi arba pavieniais būdingais atvejais, arba sistemos stebejjimu tam tikrą laiką (Rybakovas, 2009, p. 145), pavyzdžiui, nagrinejjant pavienius sèkmingų regionų atvejus, stengiamasi nustatyti veiksnius, lėmusius sẻkmingą šių regionų ekonominę ir socialinę raidą, aptarti kliūtis ir iššūkius, kuriuos teko ịveikti. Straipsnyje mokslinès literatūros analizè ir dviejų atvejų (t. y. kūrybos visuomenės politikos Lietuvoje krypčiu nustatymo ir šios politikos igyvendinimo) tyrimas (duomenims rinkti bei nagrinèti pasitelkus dokumentų analizès metodą) atliekami, sudarant kūrybos visuomenès politikos ịgyvendinimo modelį.

Longitudinè dokumentų analizė (Kardelis, 2007, p. 254; Luobikienè, 2010, p. 89) suteikia galimybę dokumentus nagrinèti ilgą laiką, ypač atliekant istorinę lyginamają tiriamų procesų analizę. Straipsnyje tokia dokumentų analizė atlikta 2011-2015 metais. Tiriant kūrybos visuomenès politiką Lietuvoje kaip paskirą gana naują politiką (kuri Lietuvoje dar oficialiai neįvardyta, bet faktiškai jau vykdoma), nagrinèjami su tuo susiję viešieji (oficialūs) dokumentai (Tidikis, 2003, p. 490-491), pavyzdžiui: Seimo nutarimai (ir jų projektai), Vyriausybės nutarimai, valstybinès (ir Europos Sajungos) strategijos, sutartys ir programos (bei jų projektai), ministrų ịsakymai, Vyriausybès komisijų posėdžių protokolai, ministerijų parengtos ataskaitos ir jų užsakymu atlikti mokslo tiriamieji darbai, oficialūs straipsniai, parengti atlikus viešuosius tyrimus, Vyriausybès ir ministerijų (ir kitose oficialiose) interneto svetainèse pateikta informacija.

Tyrimui pasirinkti bendrieji tradiciniai dokumentų analizės būdai (supratimas, intuicija, įprasminimas), nagrinèjant su kūrybos visuomenès politika susijusius viešuosius dokumentus (remiantis 4 paveiksle pateiktu dokumentų analizès metodų skirstymu). Atkreiptinas dèmesys, kad dokumentų analizès metodas - tai „pirminių duomenų rinkimas, kai dokumentai naudojami kaip pagrindiniai informacijos šaltiniai“ (Tidikis, 2003, p. 488); minètas metodas gali būti skirstomas pagal ịvairius požymius: informacijos laikmeną, tikslinę paskirtị (medžiagos, gautos remiantis paties tyrejo programa, tiksliniai faktiniai duomenys), ịasmeninimo lygi, dokumento šaltinio rūši (oficialūs ir neoficialūs šaltiniai), ,informacijos šaltinị (pirminis - tiesioginio stebèjimo ar apklausos būdu gauti duomenys; 
antrinis - apibendrinamieji arba aprašomieji pirmujų dokumentų duomenys)“ (Tidikis, 2003, p. 488). Atsižvelgiant ị tai, pagal tikslinę paskirtị tyrimui pasirinkti su kūrybos visuomenès politika susiję dokumentai (t. y. pasirinkta nagrinėti medžiagos, gautos remiantis paties tyrejo nustatyta programa, tikslinius faktinius duomenis). Atsižvelgiant ị dokumento šaltinio rūšsi, pasirinkti nagrinèti viešieji (oficialūs) dokumentai. Pažymètina, kad tyrimui taikomi bendrieji tradiciniai dokumentų analizès būdai; nagrinèjimo pagrindas šiuo atveju yra psichologijos mokslo nustatyti teksto supratimo mechanizmai. Tyrimui netaikomi formalizuoti dokumentų analizès būdai (t. y. turinio analizès metodas), kuriuos išplètojo (ir dažniausia taiko) sociologijos mokslas, siekdamas formalizuoti dokumentų nagrinèjimą bei išvengti šališkumo.

Dokumentų analizès metodai

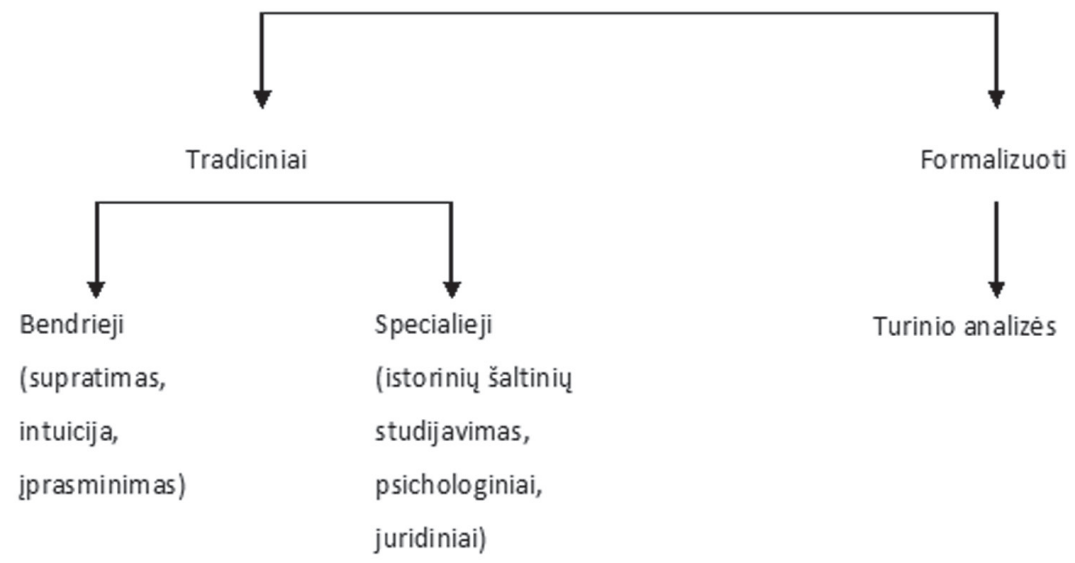

4 pav. Dokumentų analizès metodai (Tidikis, 2003, p. 490)

Fig. 4. Methods of analysis of documents (Tidikis, 2003, p. 490)

\section{Tyrimo rezultatai: kūrybos visuomenès politikos igyvendinimo modelis}

Kūrybos visuomenès politikos ịgyvendinimo modelis ( 5 pav.) sudaromas taikant mokslinès literatūros analizès metodą, pasitelkus atvejo tyrimo būdą. Sudarant ši modelị, nagrinėjami šios politikos kūrimo ir ịgyvendinimo procesai (Lietuvos atveju); papildomai atsižvelgiama ị mokslinèje literatūroje (Melnikas, 2002, p. 71) pateiktus tyrimus apie visuomenei, kaip sistemai, priskiriamas raidos, er- 
dvès bei socialinès prigimties savybes, kas lemia būtinybę įvertinti ankstesnès politikos patirtį ir šalies raidos strategijos poveikị (įvairioms sritims); remiamasi strateginio valdymo žingsniais (Vasiliauskas, 2004, p. 9) viešajame sektoriuje (kai rengiamos paskirų šalių, regionų raidos strategijos, kur minima kūrybos visuomenè).

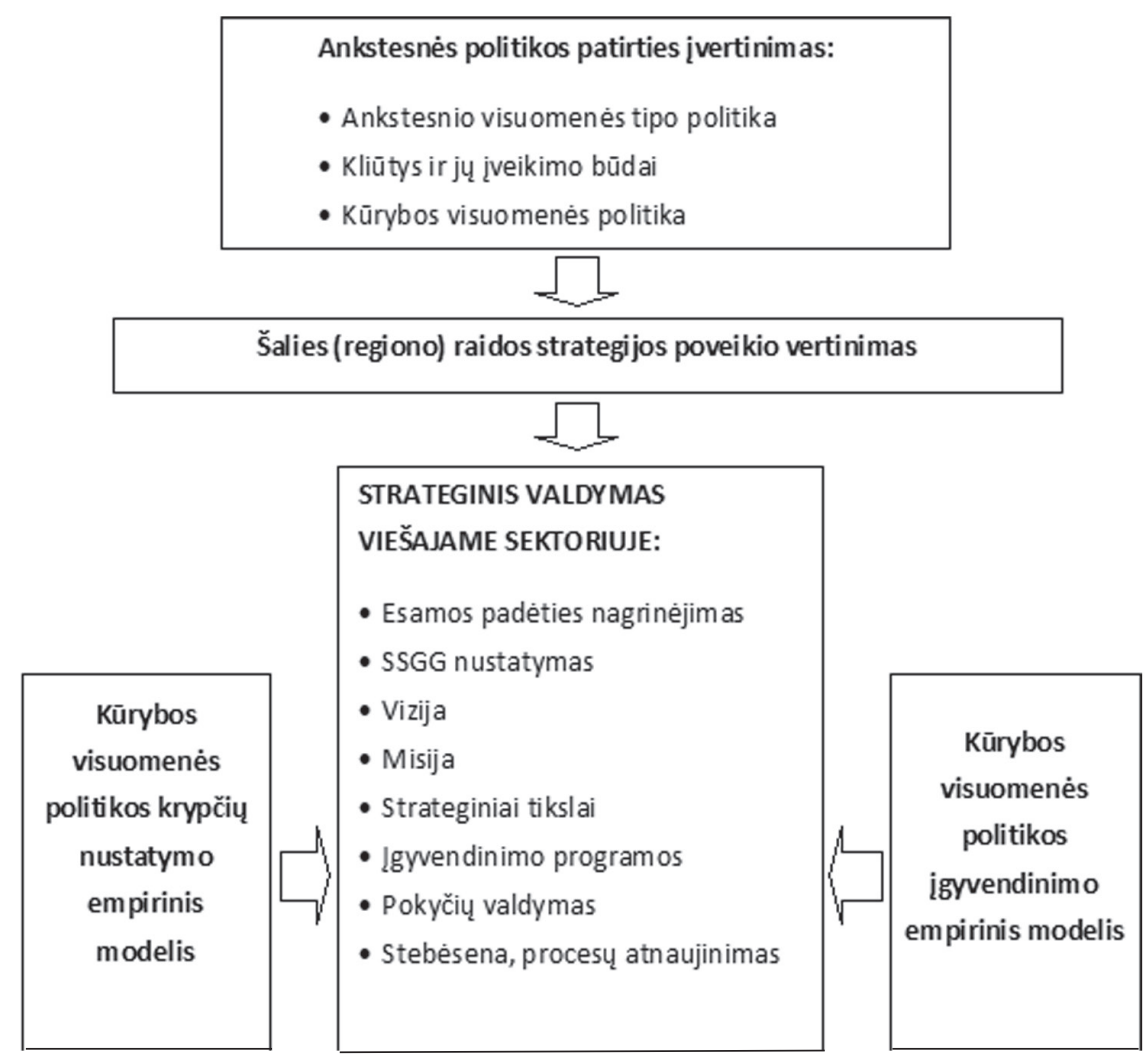

5 pav. Kūrybos visuomenès politikos igyvendinimo modelis Fig. 5. The model of implementation of creative society policy

Pagal sudarytą modelį (5 pav.) kūrybos visuomenès politika (kaip gana nauja politika) gali būti formuojama ir ịgyvendinama pavienèje šalyje. Modelị sudaro penkios dalys: ankstesnès politikos patirtis; šalies (regiono) raidos strategijos, kur minima kūrybos visuomene, poveikis įvairioms sritims; strateginio valdymo žingsniai viešajame sektoriuje; kūrybos visuomenès politikos krypčių nustatymas; 
kūrybos visuomenès politikos ịgyvendinimas. Pirmos trys dalys nustatytos mokslinès literatūros (Melnikas, 2002, p. 71; Vasiliauskas, 2004, p. 9) analizės metodu, likusios dvi - pagrịstos atlikus atvejo tyrimą.

Kaip nurodo modelis, pirmiausia svarbu ịvertinti ankstesnès politikos patirti, sukauptą vykdant šalyje ankstesnio visuomenès tipo (žinių visuomenès) politiką ir kūrybos visuomenès politiką. Tai padeda apibrěžti kliūtis, su kuriomis susidūrè ankstesnio visuomenès tipo politika, bei jų ịveikimo būdus, taip pat atskleisti kūrybos visuomenès politikos paskiroje šalyje teisinius ir organizacinius ypatumus. Siekiant tyrimo išsamumo, reikia išnagrinèti šalies (regiono) raidos strategijos poveikị (Vilpišauskas ir kt., 2005, p. 70) ịvairioms sritims. Toliau būtina įvertinti minètos strategijos rengimo ir igyvendinimo eigą. Šis etapas būtinas, remiantis pagrindiniais strateginio valdymo žingsniais (Vasiliauskas, 2004, p. 9), kurie taikomi viešojo sektoriaus strateginio planavimo metodikoje (Lietuvos Respublikos Vyriausybès nutarimas, 2011): vertinamas esamos padèties nagrinejjimas, stiprybių, silpnybių, galimybių ir grèsmių (SSGG) nustatymas, vizija, misija, strateginiai tikslai, igyvendinimo programos, pokyčiu valdymas, stebėsena ir procesų atnaujinimas (taikomas nustatytinis metodologinis požiūris ị strateginị valdymą, ịvertinant tokio požiūrio privalumus: nuoseklumą, išbaigtumą). Pažymètina, kad SSGG nustatymas įtrauktas ị modelị, atsižvelgiant ị mokslinejje literatūroje (Vasiliauskas, 2004, p. 9; Bivainis ir kt., 2009) aprašytus strateginio valdymo žingsnius viešajame sektoriuje. Remiantis šiais žingsniais, SSGG nustatymas yra svarbi kiekvienos strategijos dalis. Pokyčių valdymas taip pat ịtrauktas ị modelị, nes taip jis tampa lankstesnis. Ivvertinus minètos strategijos rengimo eigą ir igyvendinimo programas, reikia ịvertinti kūrybos visuomenès politikos krypčių nustatymą ir jų igyvendinimo galimybes. Čia taikomi kūrybos visuomenès politikos krypčiu nustatymo ir igyvendinimo empiriniai modeliai (6 ir 7 pav.), sudaryti, remiantis atitinkamų dviejų atvejų tyrimu, t. y. Lietuvoje sukaupta kūrybos visuomenès politikos (vykdomos igyvendinant šalies raidos strategiją) patirtimi.

\subsection{Kūrybos visuomenės politikos krypčių nustatymo empirinis modelis}

Šis modelis aprašo kūrybos visuomenès politikos krypčių nustatymą (rengiant šalies raidos strategiją), remiantis pavienio atvejo (tokios politikos Lietuvoje krypčių nustatymo) nagrinèjimu. Nagrinèta, remiantis keturiais viešaisiais dokumentais (,Lietuva 2030“, 2010; Lietuvos Respublikos Vyriausybė, 2010; Facebook, 2011; Lietuvos Respublikos Seimo nutarimo projektas, 2011). 

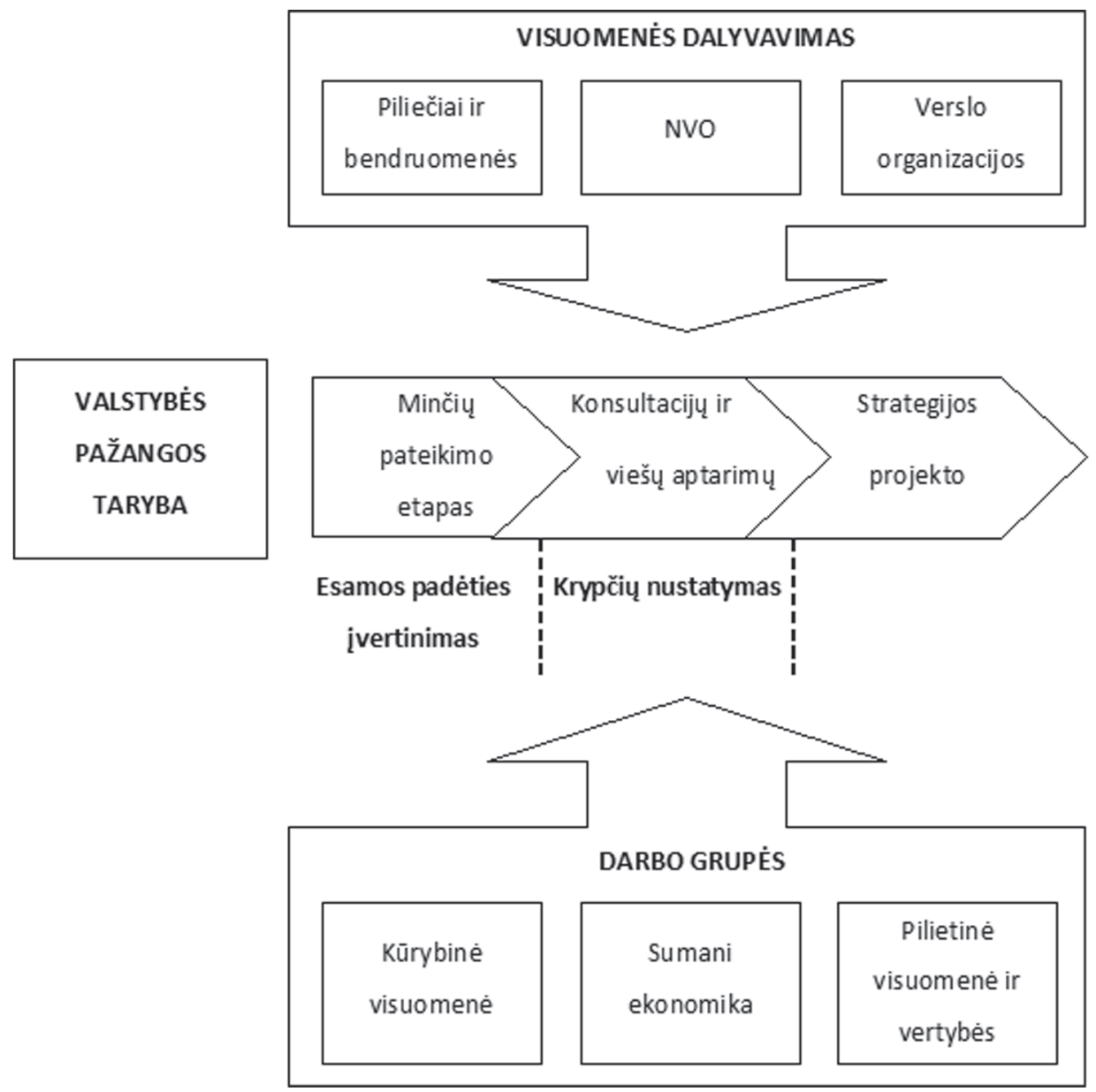

6 pav. Kūrybos visuomenės politikos krypčių nustatymo (rengiant šalies raidos strategiją) empirinis modelis

Fig. 6. The empirical model of directions' determination (during the preparation of the state development strategy)

of creative society policy

Plètotinio strateginio valdymo (Vasiliauskas, 2004, p. 11-13) nuostatų (pripažistant verslo grandžių ir visuomenės institucijų iniciatyvos svarbą) taikymą modeliui pagrindžia tokie atvejo tyrimo faktai. Kuriant šalies raidos strategiją Lietuvoje siekta kuo didesnio visuomenès sutarimo dẻl šalies vizijos ir pažangos vertybių. Atkreiptinas dėmesys, kad pagrindinis strategijos rengejas buvo visuomené, aktyviai dalyvavusi visuose rengimo etapuose. Siekiant kuo daugiau pi- 
liečių ịtraukti ị strategijos rengimą, atvirai svarstyta apie Lietuvos ateitị: šalies regionuose veikè minčių pateikimo centrai, visoje Lietuvoje buvo paskelbta minčių rinkimo diena, visą strategijos rengimo laiką veikè minčiu bankas interneto svetainèje „Lietuva 2030“ (2010). Be to, mokyklose buvo paskirta minčių Lietuvai savaitè, kai mokiniai apie Lietuvos ateitį kūrè rašinius, o gabiausieji mokiniai buvo pakviesti vykdyti projektą „Moksleiviai - i Vyriausybę“, kur pristatė savo sumanymus. Lietuvos žmonès (ir lietuviai visame pasaulyje) apie šią strategiją galëjo pateikti savo nuomonę paskelbtame viešajame pasitarime (Lietuvos Respublikos Vyriausybè, 2010). Svarbu, kad strategijos rengimą prižiūrèjo Valstybės pažangos taryba, ị kurią susibūré žinomi verslo, kultūros, meno, mokslo ir visuomenès veikèjai ir Vyriausybès atstovai. Valstybès pažangos taryba ne tik rinkosi i 7 oficialius posėdžius, bet ir dalyvavo, rengiant visą strategiją nuo minčių pateikimo centrų iki radijo laidų, kuriose buvo pristatomas strategijos projektas. Be to, Valstybės pažangos tarybos nariai dalyvavo viešuose svarstymuose ir strategijos projekto aptarimuose: ,Siekiant (...) dialogo su socialiniais ir ekonominiais partneriais, organizuotos apskritojo stalo diskusijos su Žinių ekonomikos forumu, akademine bendruomene, jaunimo ir moksleivių organizacijomis, (...) socialinių ir ekonominių partnerių asocijuotomis struktūromis, žiniasklaidos ir verslo organizacijų atstovais. Projektas taip pat buvo aptariamas su pasaulio lietuviais Lietuvos diplomatinėse atstovybėse, organizuotos konsultacijos su nevyriausybinèmis organizacijomis, surengti vieši Strategijos projekto aptarimai 5 regionuose su vietos bendruomenès ir verslo atstovais, parengtas radijo laidų, kuriose dalyvavo Valstybès pažangos tarybos ir teminių darbo grupių nariai, ciklas" (Lietuvos Respublikos Seimo nutarimo projektas, 2011, p. 32). Su strategijos rengimu susijusiai informacijai skelbti naudojama interneto svetaine „Lietuva 2030“ (2010) ir socialinè interneto svetainè (Facebook, 2011). Minèti faktai liudija verslo grandžių ir visuomenès institucijų iniciatyvos svarbos pripažinimą šiuo atveju. Modelis turi tiksliai atvaizduoti tikrovę, todèl ị kūrybos visuomenès politikos krypčių nustatymo empirinị modelị įtraukta Valstybès pažangos taryba ir visuomenès dalyvavimas (apimantis piliečius ir bendruomenes; nevyriausybines organizacijas arba NVO; verslo organizacijas).

Pažymètina, kad kūrybos visuomenės politikos krypčių nustatymas (rengiant šalies raidos strategiją) pagrịstas institucionalizmo teorijos (Parsons, 1960; Zakarevičius ir kt., 2004, p. 82) principais (tikslai nustatomi grupiniuose svarstymuose, kur dalyvauja kuo platesnis atstovų ratas; visų lygių sprendimai priimami, ịvairiais būdais ịtraukus visus susijusius atstovus). Tai rodo pavienio atvejo (kūrybos visuomenès politikos Lietuvoje krypčių nustatymo) tyrimo faktai. Valstybės pažangos taryba nagrinėjo teminių darbo grupių siūlymus ir visuomenės pateiktas mintis, 
parengė strategijos projektą, kuris plačiai aptartas su visuomene ir socialiniais atstovais. Siekiant ịvertinti esamą padètį, nagrinèti visuomenès pateiktas mintis ir rinkti pasiūlymus, sudarytos tokios darbo grupès: „Kūrybinè visuomene“, „Sumani ekonomika“, „Pilietinè visuomenè ir vertybès“, kuriose „,savanoriškai dirbo nevyriausybinių organizacijų, akademinio pasaulio, verslo organizacijų ir ministerijų atstovai, taip pat nepriklausomi konsultantai ir ekspertai“" (Lietuvos Respublikos Seimo nutarimo projektas, 2011, p. 32). Teminėse darbo grupèse apibendrinus gautą informaciją, išryškintos pagrindinès kryptys ir kūrybos visuomenès politikos kryptys (atskleidžiančios, beje, ir mokslinejje literatūroje nagrinejjamas kūrybos visuomenès politikos kryptis): veikli visuomenè (apimanti ir vidurinio mokslo sistemos keitimo bei aukštos kokybės kultūros paslaugų, kūrybos industrijų produktų iniciatyvas), solidari visuomenè (apimanti ir darnios šeimos stiprinimo iniciatyvas), besimokanti visuomenè (apimanti ir aukštojo mokslo sistemos tobulinimo iniciatyvas). Nustatant kryptis ryškus institucionalizmo principas (kryptys nustatytos, visuomenei pateikus minčių ir pasiūlymų, o darbo grupėms juos išnagrinèjus bei apibendrinus), todèl ị kūrybos visuomenès politikos krypčių nustatymo empirinị modelị ịtrauktos ir minètos darbo grupès.

Papildomai atkreiptinas dèmesys ị vartojamas sąvokas (kūrybos visuomene ir sumani visuomenè). Kaip minèta, ekspertiniu lygmeniu rengiant šalies raidos strategiją „Lietuva 2030“ dalyvavo trys teminès darbo grupès: sumanios ekonomikos, kūrybinès ir pilietinès visuomenès. Atsižvelgiant ị tai, strategijoje išskirtos esminès pažangos sritys (visuomenè, ekonomika ir valdžia), kurių pavadinimai strategijoje suvienodinti („Sumani visuomenë“, „Sumani ekonomika“ ir „Sumanus valdymas").

Straipsnyje, remiantis visuomenès raidos požiūriu (paaiškintas straipsnio pradžioje, prie kūrybos visuomenès pagrindimo), visur vartojama kūrybos visuomenès sąvoka.

\subsection{Kūrybos visuomenès politikos igyvendinimo empirinis modelis}

Šis modelis aprašo kūrybos visuomenès politikos ịgyvendinimą (remiantis šalies raidos strategija), nagrinėjant paskirą atveji (igyvendinant tokią politiką Lietuvoje). Analizei panaudoti 7 viešieji dokumentai (Lietuvos Respublikos Seimo nutarimas, 2007, 2012; „Lietuva 2030“, 2010, 2014; Lietuvos Respublikos finansų ministro ịsakymas, 2010; Lietuvos Respublikos Vyriausybės nutarimas, 2011, 2012).

Sudarant modelį, dera atkreipti dèmesi ị pagrindinị organizacinio tobulinimo (vystymo) teorijos (Beckhard, 1969, kt.) principą (valdymo tobulinimas - ne pa- 
sikartojantys ar juolab vienkartiniai veiksmai, o nuolatinis, kasdienis procesas). Tai patvirtina tokie minèto atvejo tyrimo faktai. Šalies raidos strategijos igyvendinimas Lietuvoje yra nuolatinè kintanti pažanga, kur pagrindinị vaidmenị atlieka visuomenė ir Valstybès pažangos taryba, sudaroma Vyriausybès. Tai ne vien tiesioginis strategijos krypčių ir iniciatyvų igyvendinimas, jis apima ir visuomenei svarbių klausimų sprendimą, skatina nuolatinị pažangių minčiu kūrimą. Kaip atskleidè atvejo tyrimas, šalies raidos strategijos „Lietuva 2030“ igyvendinimu rūpinasi tokie svarbiausi pažangos atstovai: Atviras pažangos forumas „Lietuva 2030“ ir Valstybès pažangos taryba su savo sekretoriatu. Atviram pažangos forumui „Lietuva 2030“ skirta palaikyti ir skatinti nuolatinị svarstymą su visuomene apie šalies raidą, prioritetus ir vertybes. Numatoma, kad forumas minčių sklaidai ir bendram svarstymui turi suburti mokslininkus, verslininkus, kultūros atstovus ir kitus veiklius visuomenès narius; šio forumo renginiai turètų vykti ne rečiau kaip 2 kartus per metus. Valstybės pažangos taryba vadovauja forumui „Lietuva 2030 “ ir jo veiklai, be to, nuolat prižiūri, kaip igyvendinama strategija, stebi rezultatus: „Valstybès pažangos taryba kiekvienais metais vertins Strategijos iniciatyvų aktualumą ir bus atsakinga už metinių pažangos darbų sąrašo sudarymą ir jo pateikimą Vyriausybei. Atsižvelgiant ị šiuos aspektus, Valstybės pažangos tarybos sudètis bus atnaujinama, siekiant ị jos veiklą ịtraukti aktyvius visuomenès (apie 50 proc.), parlamentinių frakcijų (apie 20 proc.) ir valdžios institucijų (apie 30 proc.) atstovus. Valstybės pažangos taryba į posèdžius rinksis ne rečiau kaip kartą per 3 mènesius. (...) Valstybès pažangos tarybos sekretoriatas dirbs Ministro Pirmininko tarnyboje ir bus atsakingas už Strategijos iggyvendinimo koordinavimą ir nuolatinę stebėseną valdžios institucijų lygiu“ (Lietuvos Respublikos Seimo nutarimas, 2012). Be to, Valstybès pažangos tarybos sekretoriatui pavesta nuolat dalyvauti forumo „Lietuva 2030“ renginiuose, rengiant ten vykusių svarstymų išvadas ir pateikiant pasiūlymų, kaip jas ịgyvendinti.

Plètotinio strateginio valdymo (Vasiliauskas, 2004, p. 11-13) nuostatų (pirmumo valstybès institucijų, verslo grandžiu ir visuomenès institucijų bendradarbiavimui teikimo) taikymą modeliui (7 pav.) pagrindžia tokie atvejo tyrimo faktai. Šalies raidos strategiją (kur minima kūrybos visuomenè) ketinama igyvendinti trimis pagrindinėmis kryptimis: „greitos pergalès“ - kasmet Vyriausybė ịsipareigoja ịgyvendinti dešimt svarbių darbų; sisteminis vizijos ịgyvendinimas, remiantis strateginio planavimo dokumentais (vidutinès ir trumpos trukmès planavimo dokumentus); bendruomenių ir nevyriausybinių organizacijų (NVO) tiesioginis itraukimas. Sudarant modelị, minètas igyvendinimo kryptis (Lietuvos Respublikos Seimo nutarimas, 2012) reikia paaiškinti išsamiau. 


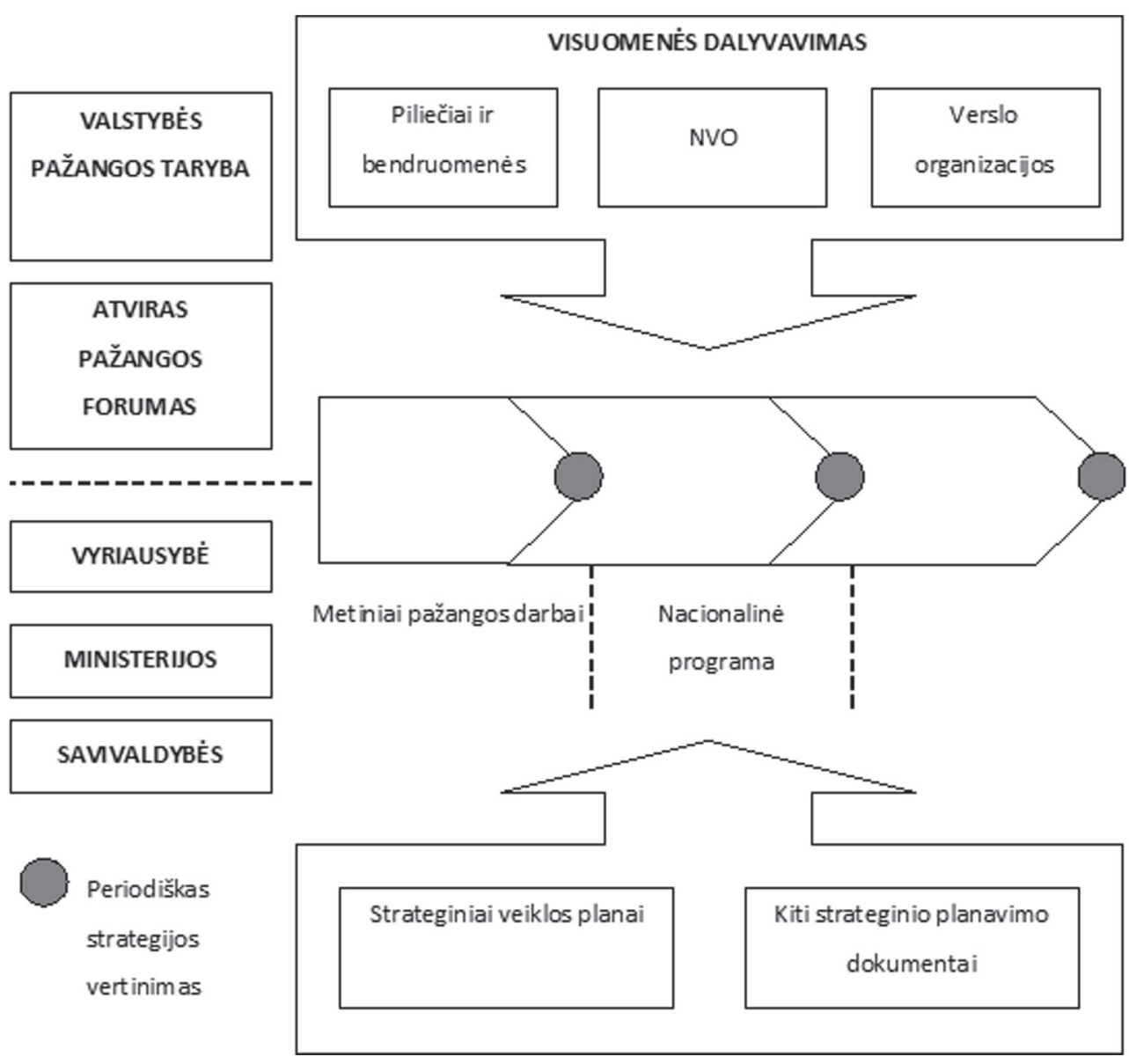

7 pav. Kürybos visuomenès politikos igyvendinimo (remiantis šalies raidos strategija) empirinis modelis (sudaryta, remiantis Lietuvos Respublikos Seimo nutarimu, 2012)

Fig. 7. The empirical model of implementation of creative society policy (through the state development strategy; basing on the Resolution of the Seimas of the Republic of Lithuania, 2012)

Pirmoji kryptis - „greitos pergalès“ - tai metiniai pažangos darbai. Atsižvelgdama į esamą padèti ir pažangą, Valstybès pažangos taryba numato kasmet išskirti dešimt būtinų pažangos darbų, kad būtų ịgyvendintos svarbiausios iniciatyvos. Šių darbų svarstymas numatytas ir atvirame forume „Lietuva 2030“. Apsvarstytų darbų sąrašą minèta taryba turi perduoti Vyriausybei, pasiūlydama įtraukti juos į kasmet tvirtinamus Vyriausybės ir ministrų prioritetus. Susiejant strategijos iniciatyvas su Vyriausybès metiniais prioritetais, užtikrinamas tuo metu reikšmingos veiklos 
igyvendinimas: „Metinių pažangos darbų įtraukimas ị Vyriausybès prioritetus yra labai reikšmingas procesas Strategijos rezultatams pasiekti, turintis poveikį ne tik einamiesiems metams, bet ir ilgesniuoju laikotarpiu. Vyriausybės prioritetams ịgyvendinti turi būti sutelkiami visi reikiami ištekliai, o tai daro tiesioginę įtaką valstybės biudžeto sudarymui. (...) Seimas, siekdamas užtikrinti efektyvų Strategijos igyvendinimą, svarstydamas pateiktą valstybès biudžeto projektą, turètų ịvertinti asignavimų paskirstymą ir Vyriausybès prioritetų sąsajas su Strategijos nuostatomis" (Lietuvos Respublikos Seimo nutarimas, 2012).

Antroji kryptis - strategijos sisteminis igyvendinimas. Numatoma, kad pažangos vertybes, apibrèžtas strategijoje, privalès atskleisti visos viešosios politikos sritys (kai bus nustatomi strateginiai tikslai ar priimami kiti svarbūs valdymo sprendimai). Strategijai igyvendinti pasitelkiama ir strateginio planavimo dokumentų sistema - šiai strategijai ịgyvendinti parengta Nacionalinès pažangos programa (Lietuvos Respublikos Vyriausybės nutarimas, 2012), kurioje numatytas Europos Sajungos finansinès pagalbos ir valstybės išteklių paskirstymas, siekiant 2014-2020 metų ilgalaikių valstybės prioritetų (Finansų ministerija paskirta atsakinga už šios programos rengimą): „Kiekviena ministerija ar Vyriausybės įstaiga tiesiogiai dalyvaus, ịgyvendinant Strategiją. Rengdamos savo strateginius veiklos planus, institucijos turès vadovautis Strategijos nuostatomis ir užtikrinti Nacionalinės pažangos programos tikslų igyvendinimą. Taigi Strategijos nuostatos turés tiesioginę įtaką institucijų veiklai“"(Lietuvos Respublikos Seimo nutarimas, 2012).

Trečioji kryptis - bendruomenių ir nevyriausybinių organizacijų tiesioginis dalyvavimas: „I Strategijos ịgyvendinimą siekiama ịtraukti visuomenę ir ịvairias jos grupes, didžiausią dèmesị skiriant bendruomenių ir nevyriausybinių organizacijų dalyvavimui. Lietuvos visuomene ir verslo organizacijos bus skatinamos savo darbais prisidèti prie pažangos krypčiu ịgyvendinimo“ (Lietuvos Respublikos Seimo nutarimas, 2012). Pažymètina, kad daug gerų darbų, skatinančių šalies pažangą, atliekama jau šiandien, tokių gerosios patirties pavyzdžiu galima surasti interneto svetainèje „Lietuva 2030“ (2014).

Atsižvelgiant ị strateginio valdymo žingsnius viešajame sektoriuje (Vasiliauskas, 2004, p. 9; Lietuvos laisvosios rinkos institutas, 2008), modelyje turi atsiskleisti ir kūrybos visuomenès politikos (igyvendinant šalies raidos strategiją) vertinimas. Kaip numato viešojo sektoriaus strateginio planavimo metodikos (Lietuvos Respublikos finansų ministro įsakymas, 2010; Lietuvos Respublikos Vyriausybės nutarimas, 2011), vertinti būtina atsižvelgiant ị rodiklius: „Strategijos ịgyvendinimo sèkmė bus vertinama, stebint pažangos rodiklių, kurie tiesiogiai nurodo pagrindinius siekiamus rezultatus iki 2030 metų, pokyčius“ (Lietuvos Respublikos Seimo nutarimas, 2012). Siekiant suderinamumo su igyvendinama strategija „Europa 2020“, šalies raidos strategijoje apibréžta, kokie rezultatai turi 
būti pasiekti jau 2020 metais. Paminètina, kad tarpinis išsamus strategijos vertinimas numatytas 2020 metais, siekiant tobulinti strategijos įgyvendinimą ir pasiekti geresnių rezultatų, tačiau tai gali būti atliekama ir dažniau (jei prisireiktų vertinti tuo metu reikšmingus strategijos ịgyvendinimo bruožus, pavyzdžiui, naudingumą, rezultatyvumą, paskirų krypčių tęstinumo poreikị ar tinkamumą). Pažymėtina, kad atvejo tyrimas rodo, jog už šios strategijos ịgyvendinimą ir planuotų rezultatų pasiekimą turi būti nuolat atsiskaitoma Valstybès pažangos tarybai bei visuomenei. Informacija apie strategijos igyvendinimo rezultatus kasmet turi būti pateikiama viešam svarstymui kaip Vyriausybès veiklos ataskaitos (kuri teikiama Seimui) dalis; vertinant pažangą, turi būti atsižvelgiama ir ị šalies ūkio konkurencingumo rodiklius (Lietuvos Respublikos Seimo nutarimas, 2007). Numatoma, kad šioje ataskaitoje turi būti ir informacija apie Vyriausybės veiklos prioritetų, tarp jų ir metinių pažangos darbų, igyvendinimą. Strategijos pažangos rodiklių švieslentę ir pažangos darbų ịgyvendinimo rezultatus galima stebėti interneto svetainèje „Lietuva 2030“ (2010).

Modelis, kaip minèta, turi tiksliai atvaizduoti tikrovę. Dėl šios priežasties ị kūrybos visuomenès politikos ịgyvendinimo empirinį modelị įtraukta: Valstybès pažangos taryba, Atviras pažangos forumas, visuomenès dalyvavimas (apimantis piliečius ir bendruomenes, nevyriausybines ir verslo organizacijas), strateginio planavimo sistema (apimanti Vyriausybę, ministerijas, savivaldybes, strateginio planavimo dokumentus), metiniai pažangos darbai ir periodiškas strategijos vertinimas.

\section{Išvados}

Kūrybos visuomenès politika yra gana naujas reiškinys. Pažymètina, kad mokslininkai ir politikai iki šiol svarsto, kokioje visuomenejje mes gyvename, kokị vaidmenį atlieka technologijos ir informacija. Tiksliau apibūdinti dabartinę visuomenę leidžia visuomenès raidos požymis. Pagal ši požymį, atsižvelgiant ị technologijų kaitą, skiriami šeši visuomenès tipai (epochos): tradicinè visuomene (iki 1800 metu), pramoniné visuomenė (1800-1950 metai), popramoninè visuomené (1950-1980 metai), žinių visuomenè - taip sutarta vadinti informacinę visuomenę pasaulio politikų UNESCO susitikime 2004 metais (1980-2000 metai), kūrybos visuomenè (nuo 2000 metų), svajonių visuomenė - būsimas tipas, aprašytas mokslininkų futurologų. Kūrybos visuomenès atsiradimą pagrindžia tyrimai apie augančią (ir nuo 2000 metų ėmusị vyrauti) kūrybos klasę dabartinèje visuomenèje ir pastaruoju metu išryškejjęs kūrybos industrijų reiškinys. Atsižvelgiant ị kūrybos klasès svarbą dabartinejje visuomenèje, galima teigti, kad kūrybos visuomenè yra visuomenès, kurioje kūrybos klasės atstovai sudaro bent 25-30 proc. visų šalies 
darbuotojų, tipas. Paminėtina, kad kūrybos klasę sudaro žmonès, dirbantys mokslo ir inžinerijos, tyrimų ir plètros, aukštosiomis technologijomis grịstose pramonės šakose (kitaip tariant, naujovėmis grịstose pramonės šakose), meno, muzikos, kultūros, estetikos ir dizaino srityse (kitaip tariant, kūrybinès veiklos srityse), taip pat žiniomis, išmanymu grịstų profesijų atstovai sveikatos apsaugos, finansinio tarpininkavimo, teisinių paslaugų ir švietimo srityse. Kūrybos visuomenès politikos, kaip gana naujos politikos, svarbą pagrindžia XXI amžiaus pradžioje atlikti tyrimai, kurie rodo, kad kultūra ir ja pagrịstas kūrybiškumas yra vienas svarbiausių Europos konkurencingumo pasaulyje šaltinių (kultūros finansavimui skiriamas didelis Europos Sajungos ir Lietuvos politiku demesys). Lietuvoje 2012 metais net įkurtas Kūrybos visuomenès ir ekonomikos institutas (Kazimiero Simonavičiaus universitete, Vilniuje) bei Kūrybinių industrijų fakultetas (Vilniaus Gedimino technikos universitete). Kūrybos visuomenès politika svarbi viešojo intereso užtikrinimo požiūriu, tokia visuomenè numatyta šalies raidos strategijoje (Lietuvoje). Kūrybos visuomenès politika gali būti apibrěžta kaip gana nauja politika (viešosios politikos sritis), įvardijanti kūrybos visuomenę ir atsiskleidžianti šalies Seimo, Vyriausybės nutarimuose ir kituose viešuosiuose dokumentuose. Kūrybos visuomenès politikos tikslas - kuo daugiau žmonių išugdyti gebėti susirasti savas igimtas kūrybines galias, toje srityje ịgyti kuo aukštesnį išsilavinimą ir gyventi bei dirbti šioje srityje savame krašte.

Nors viešosios politikos procesas yra plačiai išnagrinètas ir dažnai suvokiamas kaip paskirų žingsnių arba stadijų seka, tikrasis pasaulis yra sudėtingesnis, jis nepadalytas ị aiškiai apibrèžtus ciklus ir fazes. Tiriant kūrybos visuomenès politikos (kaip viešosios politikos srities) procesą paskiroje šalyje pastebima, kad Lietuvoje išryškejjo atitinkamos šios politikos krypčių nustatymo ir igyvendinimo stadijos. Tyrimo rezultatas - sudarytas kūrybos visuomenès politikos igyvendinimo modelis (atlikus mokslinès literatūros analizę ir dviejų atvejų tyrimą). Sudarant ši modelį, nagrinèti šios politikos kūrimo ir ịgyvendinimo procesai (Lietuvos atveju); papildomai atsižvelgta ị mokslinèje literatūroje pateiktus tyrinejjimus apie visuomenei, kaip sistemai, priskiriamas raidos, erdvès bei socialinès prigimties savybes, kas lemia būtinybę ịvertinti ankstesnès politikos patirtị ir šalies raidos strategijos poveikị (įvairioms sritims); pasiremta strateginio valdymo žingsniais viešajame sektoriuje (kai rengiamos paskirų šalių, regionų raidos strategijos, kur minima kūrybos visuomenè). Pagal sudarytą modelị kūrybos visuomenès politika (kaip gana nauja politika) gali būti formuojama ir ịgyvendinama paskiroje šalyje. Modelị sudaro penkios dalys: ankstesnès politikos patirtis; šalies (regiono) raidos strategijos, kur minima kūrybos visuomené, poveikis ịvairioms sritims; strateginio valdymo žingsniai viešajame sektoriuje; kūrybos visuomenès politikos krypčių nustatymas; kūrybos visuomenès politikos igyvendinimas (pirmos trys dalys nustatytos 
mokslinès literatūros analizès metodu, likusios dvi - pagrịstos atvejo tyrimu). Kaip nurodo modelis, pirmiausia svarbu įvertinti ankstesnès politikos patirtį, sukauptą vykdant šalyje ankstesnio visuomenès tipo (žinių visuomenès) politiką ir kūrybos visuomenès politiką. Tai padeda apibrèžti kliūtis, su kuriomis susidūrè ankstesnio visuomenès tipo politika, ir jų įveikimo būdus, be to, atskleisti kūrybos visuomenès politikos paskiroje šalyje teisinius ir organizacinius ypatumus. Siekiant tyrimo išsamumo, reikia išnagrinèti šalies (regiono) raidos strategijos poveikị ịvairioms sritims. Būtina ịvertinti minètos strategijos rengimo ir ịyvendinimo eigą. Šiame etape remiamasi pagrindiniais strateginio valdymo žingsniais, kurie taikomi viešojo sektoriaus strateginio planavimo metodikoje (vertinami šie žingsniai: esamos padèties nagrinèjimas, stiprybių, silpnybių, galimybių ir grèsmių nustatymas, vizija, misija, strateginiai tikslai, igyvendinimo programos, pokyčių valdymas, stebėsena, procesų atnaujinimas). Ivertinus minètos strategijos rengimo eigą ir jos igyvendinimo programas, svarbu ịvertinti kūrybos visuomenès politikos krypčiu nustatymo ir jų igyvendinimo galimybes. Čia taikomi kūrybos visuomenès politikos krypčių nustatymo ir igyvendinimo empiriniai modeliai, sudaryti, remiantis dviejų atvejų tyrimu, t. y. Lietuvoje sukaupta kūrybos visuomenès politikos (vykdoma iggyvendinant šalies raidos strategiją) patirtimi.

Atskleistos kūrybos visuomenès politikos Lietuvoje kryptys, nustatytos rengiant šalies raidos strategiją (atlikus krypčiu nustatymo Lietuvoje atvejo tyrimą): veikli visuomenè, solidari visuomenè, besimokanti visuomenè. Atvejo tyrimas parodè, kad kryptys Lietuvoje nustatytos laikantis institucionalizmo teorijos principų: visuomenei pateikus minčių ir pasiūlymų, teminèms darbo grupėms („Kūrybinė visuomenë“, „Sumani ekonomika“, „Pilietinẻ visuomenè ir vertybės") juos išnagrinejjus bei apibendrinus (todèl ị kūrybos visuomenès politikos krypčių nustatymo empirini modeli i itrauktos ir darbo grupès). Paminètina, kad šios kryptys atitiko ir mokslinejje literatūroje nagrinejjamas kūrybos visuomenès politikos kryptis (veikli visuomenė apėmè ir vidurinio mokslo sistemos keitimo bei aukštos kokybès kultūros paslaugų, kūrybos industrijų produktų iniciatyvas; solidari visuomenè apėmè ir darnios šeimos stiprinimo iniciatyvas; besimokanti visuomené apėmė ir aukštojo mokslo sistemos tobulinimo iniciatyvas).

Atskleistos kūrybos visuomenès politikos Lietuvoje ịgyvendinimo (igyvendinant šalies raidos strategiją) kryptys (atlikus igyvendinimo Lietuvoje atvejo tyrimą): 1) „greitos pergalès“ (kasmet Vyriausybè ịsipareigoja ịgyvendinti dešimt svarbių darbų); 2) sisteminis strategijos įgyvendinimas (remiantis strateginio planavimo dokumentais - vidutinès ir trumpos trukmès; be to, svarbu atsižvelgti i papildomą veiksni - būtinybę turèti šiai politikai tinkamą instituciją, kuri turètų galią prižiūrèti visų lygmenų strategijų rengimo ir ịgyvendinimo eigą); 3) bendruomenių bei nevyriausybinių organizacijų tiesioginis įtraukimas. Atvejo tyrimas 
patvirtino, kad tokios politikos igyvendinimas Lietuvoje pagristas pagrindiniu organizacinio tobulinimo (vystymo) teorijos principu (valdymo tobulinimas - tai ne pasikartojantys ar juolab vienkartiniai veiksmai, o nuolatinis, kasdienis procesas), i kūrybos visuomenès politikos igyvendinimo empirini modeli įtraukta Valstybès pažangos taryba, Atviras pažangos forumas, visuomenès dalyvavimas (apimantis piliečius ir bendruomenes; nevyriausybines organizacijas; verslo organizacijas), strateginio planavimo sistema (apimanti Vyriausybę, ministerijas, savivaldybes ir strateginio planavimo dokumentus), metiniai pažangos darbai ir periodiškas strategijos vertinimas.

\section{Literatūra}

Anderson, J. E. (2015). Public policymaking: an introduction. 8th ed. Stamford: Cengage Learning. Beckhard, R. (1969). Organizational Development: Strategies and Models. Addison-Wesley.

Bivainis, J., Tunčikienè, Ž. (2009). Viešojo sektoriaus institucijų strateginis planavimas. Vilnius: Technika.

Caves, R. (2002). Creative Industries: Contracts Between Arts and Commerce. Cambridge: Harvard University Press.

Dunn, W. N. (2006). Viešosios politikos analizė: ịvadas. Vilnius: Homo liber.

European Commission. (2012). Europe 2020: flagship initiatives. Prieiga internete: http://ec.europa.eu/ europe2020/reaching-the-goals/flagship-initiatives/index_en.htm [žiūrèta 201203 26].

Europos Komisija. (2010). Žalioji knyga: kultūros ir kūrybos sektoriu potencialo išlaisvinimas. Briuselis. Prieiga internete: http://eur-lex.europa.eu/LexUriServ/LexUriServ.do?uri=COM:2010:0183:FIN:LT:PDF [žiūrèta $20140916]$.

Facebook. (2011). Lietuva 2030. Prieiga internete: http://www.facebook.com/Lietuva2030 [žiūrèta 201112 09].

Flick, U. (2017). An Introduction to Qualitative Research. 5th ed. Sage.

Florida, R. (2002). The Rise of the Creative Class. And How It's Transforming Work, Leisure and Everyday Life. Basic Books. Prieiga internete: http://www.marioruiz.info/portfolio/id/creative_class_analysis_2.pdf [žiūrèta 201307 09].

Florida, R. (2012). The Rise of the Creative Class - Revisited. Basic Books. Prieiga internete: http:// martinprosperity.org/2012/07/10/insight-rise-revisited-tape/ [žiūrèta 201310 17].

Florida, R., Tinagli, I. (2004). Europe in the Creative Age. Demos. Prieiga internetą: http://www.creativeclass. $\mathrm{com} / \mathrm{rfcgdb} / \mathrm{articles} /$ Europe_in_the_Creative_Age_2004.pdf. [žiūrèta 201605 19].

Gelūnas, A. (2010). Kultūros politikos kaita šalies pažangai. Straipsnis pristatytas konferencijoje Kultūra ir kūrybiškumas Lietuvos pažangai, kuri vyko Vilniuje, 2010 m. gruodžio 2-3 d.

Giest, S., Howlett, M., Mukherjee, I. (2015). The relevance of the academic study of public policy. In G. Stoker, J. Pierre, B. G. Peters (ed.). The relevance of political science. London: Palgrave Macmillan, p. 121-135.

Jensen, R. (2004). Svajonių visuomene: kaip artejjantis perëjimas nuo informacijos prie vaizduotès pakeis jūsu verslą. Vilnius: D. Radkevičiaus PI „Rgrupe““.

Kačerauskas, T. (2017). Kürybos visuomenè. 2-asis patais. leid. Vilnius: Technika. Prieiga internete: http:// leidykla.vgtu.lt/lt/knyga/monografijos/2952.html?Itemid=4 [žiūrèta 201707 28].

Kardelis, K. (2007). Moksliniu tyrimu metodologija ir metodai. 4-asis leid. Šiauliai: Lucilijus.

KEA. (2006). The Economy of Culture in Europe. Prieiga internete: http://ec.europa.eu/culture/library/studies/ cultural-economy_en.pdf [žiūrèta 201409 16].

KEA. (2009). The Impact of Culture on Creativity. Prieiga internete: http://www.keanet.eu/studies-andcontributions/the-impact-of-culture-on-creativity/ [Žiūrèta 201409 16].

KEA. (2011). Mapping the Cultural and Creative Sectors in the EU and China: A Working Paper in support to the development of an EU-China Cultural and Creative Industries' (CCIs) platform. Prieiga internete: http:// www.keanet.eu/studies-and-contributions/mapping-the-cultural-and-creative-sectors-in-the-eu-and-china/ [žiūrèta 201409 16].

Kingdon, J. W. (2014). Agendas, alternatives, and public policies. 2nd ed. Harlow: Pearson. 
Kirvelis, D. (2007). Kūrybinės klasės ir kūrybinės visuomenės koncepcija. Straipsnis pristatytas konferencijoje Informacijos, žiniu ar kürybine visuomenè?, kuri vyko Vilniuje $2007 \mathrm{~m}$. spalio $24 \mathrm{~d}$. Prieiga internete: http://www3.lrs.lt/pls/inter/w5_show?p_r=5640\&p_k=1 [žiūrèta 201606 20].

Kirvelis, D. (2011). Lietuvos ateities vizija. Prieiga internete: http://web.vu.lt/gf/d.kirvelis/2011/11/28/lietuvosateities-vizija/ [žiūrèta 20141104$]$.

Kvietkauskas, R. (2011). Kultūros politikos kaitos gairių ịgyvendinimo priemonių planas. Pranešimas pristatytas seminare Kultūros politikos prioritetai, kuris vyko Vilniuje 2011 m. vasario 7 d. Prieiga internete: http:// dainius.org/?p=5616 [žiūrèta 20120105 ].

Lietuva 2030. (2010). Naudinga informacija. Prieiga internete: https://www.lietuva2030.1t/lt/naudinga [žiūrèta $20120104]$.

Lietuva 2030. (2014). Geroji patirtis. Prieiga internete: http://lietuva2030.lt/old/geroji-patirtis, [žiūrèta 201501 02].

Lietuvos laisvosios rinkos institutas. (2008). Viešojo sektoriaus strateginis planavimas: iššükiai ir sprendimai [tyrimas]. Vilnius. Prieiga internete: http://www.llri.lt/naujienos/ekonomine-politika/finansai-pinigupolitika/analize-viesojo-sektoriaus-strateginis-planavimas-issukiai-ir-sprendimai/lrinka [žiūrèta 201607 13].

Lietuvos Respublikos finansu ministro įsakymas. (2010). Dèl Strateginio planavimo dokumentuose naudojamu vertinimo kriteriju sudarymo ir taikymo metodikos patvirtinimo. Spalio 25 d., Nr. 1K-330. Vilnius. Prieiga internete: http://www3.1rs.lt/pls/inter3/dokpaieska.showdoc_1?p_id=384507\&p_query=\&p_tr2=2 [žiūrèta $20120105]$.

Lietuvos Respublikos Seimo nutarimas. (2007). Dèl šalies ūkio konkurencingumo sèkmès rodikliu bei žiniu ir inovaciju infrastruktūros valstybei svarbiu ekonominiu projektu patvirtinimo. Birželio $26 \mathrm{~d}$., Nr. X-1225. Vilnius. Prieiga internete: http://www3.1rs.1t/pls/inter3/dokpaieska.showdoc_1?p_id=301017\&p_tr2=2 [žiūrèta 20150102 ].

Lietuvos Respublikos Seimo nutarimas. (2012). Dél Valstybės pažangos strategijos ,Lietuvos pažangos strategija „Lietuva 2030“ patvirtinimo. Gegužès 15 d., Nr. XI-2015. Vilnius. Prieiga internete: http://www3.lrs.lt/pls/ inter3/dokpaieska.showdoc_1?p_id=425517\&p_query=\&p_tr2=2, [žiūrèta 20150102 ].

Lietuvos Respublikos Seimo nutarimo projektas. (2011). Dél Valstybės pažangos strategijos ,Lietuvos pažangos strategija „Lietuva 2030“ patvirtinimo. Lapkričio 28 d., Nr. XIP-3889. Vilnius. Prieiga internete: http:// www3.lrs.lt/pls/inter3/dokpaieska.showdoc_1?p_id=412556\&p_query=\&p_tr2=2, [žiūrèta 20120103 ].

Lietuvos Respublikos Vyriausybè. (2010). Lietuva 2030. Prieiga internete: http://www.lrv.lt/ [žiūrèta 20120105 ].

Lietuvos Respublikos Vyriausybès nutarimas. (2011). Dél Strateginio planavimo metodikos patvirtinimo. Balandžio 20 d., Nr. 827. Vilnius. Prieiga internete: http://www3.1rs.lt/pls/inter3/dokpaieska.showdoc_1?p_ $\mathrm{id}=397970 \& p$ query $=\& p$ tr2=2, [žiūrèta 20120105$]$.

Lietuvos Respublikos Vyriausybės nutarimas. (2012). Dél 2014-2020 metu nacionalinès pažangos programos patvirtinimo. Lapkričio 28 d., Nr. 1482. Vilnius. Prieiga internete: http://www3.lrs.lt/pls/inter3/dokpaieska. showdoc_1?p_id=439028 [žiūrèta 20150102$].$

Lindblom, Ch. E., Woodhouse, E. J. (1999). Politikos formavimo procesas. Vilnius: Algarvè.

Luobikienè, I. (2010). Sociologiniu tyrimu metodika. 7-asis patais. ir papild. leid. Kaunas: Technologija.

Melnikas, B. (2002). Transformacijos: visuomenès pokyčiai, naujas tūkstantmetis, valdymas ir savireguliacija, Rytu ir Vidurio Europa. Vilnius: Vaga.

Oficialiosios statistikos portalas. (2015). Užimti gyventojai pagal ekonominès veiklos rūšis. Prieiga internete: http://osp.stat.gov.lt/temines-lenteles20 [žiūrèta 201605 19].

Parsons, D. W. (2001). Viešoji politika: politikos analizės teorijos ir praktikos ịvadas. Vilnius: Eugrimas.

Parsons, T. (1960). Structure and Process in Modern Societies. Glancoe.

Remeika, R., Čepaitis, R. (2007). Kūrybinès visuomenės kūrimo strategijos problemos Lietuvoje. Straipsnis pristatytas konferencijoje Informacijos, žinių ar kūrybiné visuomené?, kuri vyko Vilniuje $2007 \mathrm{~m}$. spalio 24 d. Prieiga internete: http://www3.lrs.lt/pls/inter/w5 show?p_r=5640\&p_k=1 [žiūrèta 201606 20].

Rybakovas, E. (2009). Interesais grindžiamas regiono vystymas. Daktaro disertacija. Kaunas: Kauno technologijos universitetas.

Stone, D. A. (2004). Viešosios politikos paradoksai: sprendimu priemimo menas politikoje. Vilnius: Eugrimas.

The European Foresight Monitoring Network. (2008). Collection of EFMN Briefs. Part 1. Prieiga internete: https://ec.europa.eu/research/social-sciences/pdf/other_pubs/efmn-report_en.pdf [žiūrèta 20160523 ].

Tidikis, R. (2003). Socialiniu mokslu tyrimu metodologija. Vilnius: Lietuvos teisès universiteto Leidybos centras.

Tvede, L. (2016). The Creative Society: How the Future Can be Won. 2nd ed. LID Publishing. 
Van Thiel, S. (2014). Research Methods in Public Administration and Public Management: An Introduction. Routledge.

Vareikis, E. (2012). Svajoniu bendruomenè: juodraštis. Vilnius: Eugrimas.

Vasiliauskas, A. (2004). Nacionalinès ekonomikos plètros strateginis valdymas: nustatytinis ir plètotinis metodologiniai požiūriai. Pinigu studijos, Nr. 3, p. 5-18. Prieiga internete: http://www.ebiblioteka.lt/ resursai/DB/LB/LB_pinigu_studijos/Pinigu_studijos_2004_03_01.pdf [žiūrèta 201307 30].

Vilpišauskas, R., Nakrošis, V. (2005). Ko verta politika? Vilnius: Eugrimas.

World Bank. (2013). China 2030: Building a Modern, Harmonious, and Creative Society. World Bank Publications. Prieiga internete: http://siteresources.worldbank.org/EASTASIAPACIFICEXT/ Resources/226300-1363837020207/china2030_final.pdf [žiūrèta 201304 11].

Zakarevičius, P., Kvedaravičius, J., Augustauskas, T. (2004). Organizaciju vystymosi paradigma. Kaunas: Vytauto Didžiojo universiteto leidykla.

\section{ON THE DISCOURSE OF IMPLEMENTATION OF A CREATIVE SOCIETY POLICY MODEL}

\section{Aurimas Venckūnas}

Summary

The article is dedicated to creative society policy (i.e. the model of its implementation in Lithuania), investigating the empirical process of public policy. Problem: how the implementation of creative society policy (as a rather new policy) is performed in a separate country. Aim of research is to make the model of implementation of creative society policy, showing the empirical process of public policy in Lithuania.

Tasks:

- To ground the creative society policy as a separate and rather new policy (grounding the creative society and the importance of its policy);

- To make an empirically based model of implementation of creative society policy;

- To reveal the directions of formation of creative society policy in Lithuania;

- To reveal the directions of implementation of creative society policy in Lithuania.

Ways and methods of research are: analysis of scientific literature (a general method), two cases' (i.e. directions' determination and implementation of creative society policy in Lithuania) study, a long-term (longitudinal) analysis of documents (performed in 2011-2015).

Results and conclusions:

Creative society policy is a rather new policy (a new phenomenon). It should be noted that scientists and politicians have been discussing the character of contemporary society and the role of technologies and information in it. However, his- 
torical approach to society development helps to describe contemporary society more precisely. Considering the change of technologies, this approach distinguishes six society types (epochs): traditional society (until 1800), industrial society (1800-1950), post-industrial society (1950-1980), knowledge society - as was agreed to call information society at the world politicians UNESCO meeting in 2004 (1980-2000), creative society (since 2000), dream society - future type, described by futurology scientists (Jensen, 2004; Vareikis, 2012; etc). The appearance of creative society is grounded by the research (Florida, 2002, p. 5; Kirvelis, 2007, p. 78) about the increasing (and dominating since 2000) amount of the creative class (consisting of 2 parts: super-creative core and creative professionals) in contemporary society, as well as by the recently appeared phenomenon of creative industries (Caves, 2002; etc). Considering the importance of the creative class in contemporary society, it can be concluded that creative society is a separate society type where the representatives of the creative class make at least 25-30 percent of all employees of the country (Kirvelis, 2007, p. 28; Florida etc, 2004, p. 14). It can be noted that the creative class consists of people employed in science and engineering, research and development, high technology industries (i.e. in innovation-based industries), in arts, music, culture, aesthetics and design (i.e. in creative occupations), as well as of representatives of knowledge-based occupations in healthcare, financial and legal services, education. The importance of creative society policy, as a rather new policy, is grounded by the research (KEA, 2006, 2009) of the $21^{\text {st }}$ century, showing that culture-based creativity is one of the most important sources of European competitiveness in the world (politicians of the European Union and Lithuania pay much attention to financing of culture). Moreover, in Lithuania in 2012, there were established: Creative Society and Economy Institute (at Kazimieras Simonavičius University in Vilnius) and Faculty of Creative Industries (at Vilnius Gediminas Technical University). Furthermore, creative society policy is important in the point of view of public interest, such society is declared in the state development strategy (in Lithuania). All in all, creative society policy can be defined as a rather new policy (a public policy area), mentioning the creative society and performed through the resolutions of the Parliament and the Government in a separate country, as well as through other public documents. Aim of creative society policy (Kirvelis, 2011, p. 6): as many people as possible are raised to discover their own creative abilities, to obtain as possibly higher education for these abilities, and to live and be employed with these abilities in their own country.

Public policy process is broadly analysed and often understood as a sequence of separate steps, or stages; however, the real world is more complicated, and it is not devided into clearly defined cycles or phases. Investigating the process of creative 
society policy (as a public policy area) in a separate country (Lithuania), the stages of directions' determination and implementation of this policy can be perceived. Research results are the model of implementation of creative society policy (having performed analysis of scientific literature and two cases' study). For making of this model, the processes of formation and implementation of this policy (in the case of Lithuania) were analysed; moreover, the properties (development, space, social origin) of society, as a system, given in scientific literature, were considered - that require to evaluate experience of previous policy and influence of the state development strategy (on different sectors); furthermore, strategic management steps in the public sector (while preparing the state, or region, development strategies that declare creative society) were considered. The model shows how creative society policy (as a rather new policy) can be formed and implemented in a separate country. The model consists of five parts: experience of previous policy; influence of the state (or region) development strategy (declaring creative society) on different sectors; strategic managent steps in the public sector; directions' determination of creative society policy; implementation of creative society policy (the first three parts are determined in the method of analysis of scientific literature, and the last two parts are grounded on two cases' study). According to the model, it is firstly important to evaluate the experience of previous policy, having performed the previous society type (knowledge society) policy and creative society policy in a country. Thus, it is possible to define problems of the previous society type policy, and their solutions, as well to reveal legal and organizational aspects of creative society policy in a separate country. For particularity reasons, influence of the state (region) development strategy on different sectors should be analysed, too. Moreover, it is necessary to evaluate the formation and implementation process of the previously mentioned strategy. This stage is made according to the main strategic management steps applied in strategic planning methodology for the public sector (i.e. analysis of current situation; determination of strengths, weaknesses, opportunities and threats, or SWOT; vision; mission; strategic goals; implementation programs; change management; monitoring and renewal of processes should be evaluated). Having evaluated the formation process and implementation programs of the previously mentioned strategy, it is necessary to evaluate directions' determination of creative society policy, and their implementation possibilities. Here, the empirical models of directions' determination and implementation of creative society policy are used; they were made basing on two cases' study, i.e. on the experience of creative society policy (performed through the state development strategy) in Lithuania.

The following directions (determined during the preparation of the state development strategy) of creative society policy in Lithuania were revealed (having 
performed the case study of directions' determination in Lithuania): active society, solidary society, learning society. The case study showed that directions' determination in Lithuania was based on the principles of the institutional theory: directions were determined only after society gave ideas and suggestions, and the thematic working groups ("Creative society", "Smart economics", and "Civil society and values") analysed and generalized them (due to this reason, the working groups were included in the empirical model of directions' determination of creative society policy, too). It should be mentioned that these directions reflected the directions of creative society policy given in scientific literature (active society included initiatives for change of the general education system, for high quality culture services and creative industry products etc; solidary society included initiatives for strengthening of the harmonious family etc; learning society included initiatives for development of the higher education system etc).

The following directions of implementation of creative society policy (through the state development strategy) in Lithuania were revealed (having performed the case study of implementation in Lithuania): "quick wins" (commitment of the Government to take 10 important actions every year); systemic implementation of this strategy (through the system of strategic planning documents - medium and short-term planning documents; as well, it is essential to consider one more factor here, i.e. it is essential to have the proper institution, with the necessary powers to control the preparation and implementation of strategies in all levels); direct involvement of communities and non-governmental organizations, or NGO. The case study proved that implementation of this policy in Lithuania was based on the main principle of the organizational development theory (development of management - this is not repeated or even onetime actions but a constant, daily process), and the following items were included in the empirical model of implementation of creative society policy: the State Progress Council, the Open Progress Forum, participation of society (including citizens and communities; non-governmental organizations; business organizations), the strategic planning system (including the Government, ministries, municipalities, and strategic planning documents), annual progress actions, periodical evaluation of this strategy. 